\title{
Eksistensi BUMN sebagai Korporasi yang Dikuasai Negara
}

\author{
Oleh:
}

\section{Agus Adhari}

\begin{abstract}
Indonesian state owned enterprises (BUMN) is a corporation, which is a large part or entirely (stoke) controlled by the state. State presents through Indonesian state-owned enterprises in order to carry out the mandate of Article 33 of UUD 1945, where the economic sectors that dominate the life of people controlled by the state. BUMN as a corporation must be clarified, either its functions or its objectives. Article 4 (1) of Law No 19 of 2003 on state enterprises, should be explanatory, that the state is only the owners of capital, and no longer consider $B U M N$ as a state institution funded by the state. BUMN as a corporation should be clarified either in law or on the level of implementation. The number of government's intervention in $B U M N$, shows that the country is not ready to have a corporation in order to carry out the mandate of Article 33 of the Constitution of 1945. It makes BUMN intervened by political interests, rather than corporate interests.
\end{abstract}

Keywords: Indonesian State owned enterprises, Stoke, Corporation.

PENDAHULUAN

Perdebatan mengenai eksistensi Badan Usaha Milik Negara sebagai Korporasi atau lembaga negara beranjak dari intervensi negara secara politik pada BUMN hingga menyandera BUMN menjadi tidak leluasa untuk bergerak, sehingga perannya dalam memberikan pemasukan kepada negara melalui pajak dan deviden tidak maksimal terlaksana. Ketentuan penyelenggaraan BUMN telah diatur dalam UU No 19 Tahun 2003 tentang BUMN dimana kepemilikan negara terhadap BUMN terbatas pada kepemilikan modal. Ketentuan ini terlihat pada Pasal 1 angka 2 UU BUMN yang menjelaskan Perusahaan Perseroan, yang selanjutnya disebut Persero, adalah BUMN yang berbentuk perseroan terbatas yang modalnya terbagi dalam saham yang seluruh atau paling sedikit $51 \%$ (lima puluh satu persen) sahamnya dimiliki oleh Negara Republik Indonesia yang tujuan utamanya mengejar keuntungan.
Kemudian Pada angka 5 disebutkan menteri yang ditunjuk dan/atau diberi kuasa untuk mewakili pemerintah selaku pemegang saham negara pada Persero dan pemilik modal pada Perum dengan memperhatikan peraturan perundang- undangan. Menteri yang dimaksud adalah Menteri BUMN. Selanjutnya Pasa 4 (1) menjelaskan jika Modal BUMN merupakan dan berasal dari kekayaan negara yang dipisahkan.

Pada putusan Mahkamah Konstitusi No 48 /PUU-XI/2013 yang dibacakan tanggal 18 September 2014, telah mengukuhkan status kekayaan negara yang bersumber dari keuangan negara dan dipisahkan dari APBN untuk disertakan menjadi penyertaan modal di BUMN tetap menjadi bagian dari rezim keuangan negara. Dengan demikian perdebatan secara hukum mengenai eksistensi keuangan BUMN sudah final. Namun tidak berarti keputusan tersebut tidak berpengaruh terhadap kedudukan BUMN sebagai korporasi yang berbadan hukum privat. 
Pasca putusan tersebut, arah kedudukan BUMN khususnya Perseroan Terbatas, menjadi tidak jelas, di satu sisi keuangan BUMN menjadi keuangan negara dan disisi lain BUMN bukan lembaga negara dimana pembiayaan pengelolaan BUMN tidak dapat disamakan dengan lembaga negara. Pengelolaan keuangan lembaga negara dilakukan untuk penyelenggaraan pemerintahan dan orientasinya adalah pelayanan publik, sementara keuangan BUMN berorientasi sebagai modal yang harus diputar dalam mekanisme bisnis guna mencari keuntungan yang nantinya dibagikan melalui mekanisme deviden pada pemerintah selaku pemegang saham. Oleh sebab itu penting mendefinisikan kembali eksistensi BUMN sebagai korporasi atau lembaga negara dalam penyelenggaraan pemerintahan di Indonesia.

\section{HAK MENGUASAI}

Pasal 33 (2) UUD 1945 menyatakan Cabang-cabang produksi yang penting bagi Negara dan yang menguasai hajat hidup orang banyak dikuasai oleh Negara. Terlebih dahulu harus dibahas makna "dikuasai" dalam ayat tersebut.

Menurut Van Vollenhoven, negara sebagai organisasi tertinggi dari bangsa yang diberi kekuasaan untuk mengatur segalagalanya dan negara berdasarkan kedudukannya memiliki kewenangan untuk peraturan hukum. ${ }^{1}$ Dalam hal ini kekuasaan negara selalu dihubungkan dengan teori kedaulatan (sovereignty atau souverenitet). Sedangkan menurut J.J. Rousseau menyebutkan bahwa kekuasaan negara sebagai suatu badan atau organisasi rakyat bersumber dari hasil perjanjian masyarakat

\footnotetext{
1 Notonagoro, Politik Hukum dan Pembangunan Agraria, Jakarta: Bina Aksara, 1984, hlm. 99.

2 R. Wiratno, dkk, Ahli-Ahli Pikir Besar tentang Negara dan Hukum, Jakarta: Pembangunan, 1958, hlm. 176.

${ }^{3}$ Carl Joachim Frederich, The Philosophy of Law in Historical Presfective, Second Edition, Chicago: University Chicago Press, 1968, hlm. 58.
}

(contract soscial) yang esensinya merupakan suatu bentuk kesatuan yang membela dan melindungi kekuasaan bersama, kekuasaan pribadi dan milik setiap individu. ${ }^{2}$ Dalam hal ini pada hakikatnya kekuasaan bukan kedaulatan, namun kekuasaan negara itu juga bukanlah kekuasaan tanpa batas, sebab ada beberapa ketentuan hukum yang mengikat dirinya seperti hukum alam dan hukum Tuhan serta hukum yang umum pada semua bangsa yang dinamakan leges imperii. ${ }^{3}$

Penafsiran mengenai konsep penguasaan negara terhadap Pasal 33 UUD 1945 juga dapat kita cermati dalam Putusan MK mengenai kasus-kasus pengujian undangundang terkait dengan sumber daya alam. Mahkamah dalam pertimbangan hukum Putusan Perkara UU Migas, UU Ketenagalistrikan, dan UU Sumber Daya Air (UU SDA) menafsirkan mengenai "hak menguasai negara (HMN)" bukan dalam makna negara memiliki, tetapi dalam pengertian bahwa negara hanya merumuskan kebijakan (beleid), melakukan pengaturan (regelendaad), melakukan pengurusan (bestuursdaad), melakukan pengelolaan (beheersdaad), dan melakukan pengawasan (toezichthoundendaad). ${ }^{4}$

Dengan demikian jelas bahwa penguasaan negara dalam Pasal 33 UUD 1945 tidak diartikan sebagai pemilik seperti yang dimaksud dalam hukum perdata. Pembatasan prasa dikuasai negara menjadi dasar pemikiran bahwa seluruh kekayaan negara sebenarnya miliki masyarakat, dengan pendekatan teori kontrak sosial menjadi penyerahan kekuasaan yang sebelumnya dimiliki oleh masyarakat kepada negara untuk dikelola guna memberikan

4 Poan Muhammad Fariz, Penafsiran Konsep Penguasaan Negara Berdasarkan Pasal 33 UUD 1945 dan Putusan Mahkamah Konstitusi, www.jurnalhukum.blogspot.co.id diakses 5 Agustus 2015. 
manfaat sebesar-besarnya demi kesejahteraan masyarakat.

Pembatasan kata "dikuasai" juga bertujuan menghindarkan dari klaim negara yang didalamnya terdapat manusia yang diberikan kekuasaan agar tidak menyelahgunakan kekuasaan tersebut untuk kepentingan pribadinya dan golongannya saja.

\section{KEPEMILIKAN BUMN}

Ilmu hukum mengenal dua subjek hukum, yaitu orang dan badan hukum. Badan hukum didefinisikan dalam Black's Law Dictionary sebagai " $a$ body, other than a natural person, that can function legally, sue or be sued, and make dicisions through agents.".

Perseroan terbatas adalah suatu persekutuan untuk menjalankan usaha yang memiliki modal terdiri atas saham-saham, yang pemiliknya memiliki bagian sebanyak saham yang dimilikinya. Badan hukum perseroan memiliki kemampuan untuk melakukan tindakan hukum sebagaimana subjek hukum yang lain. ${ }^{6}$

Pasal 1 angka 1 UU No. 40 Tahun 2007 tentang Perseroan Terbatas mendefinisikan "Perseroan terbatas adalah Perseroan Terbatas, yang selanjutnya disebut perseroan, adalah badan hukum yang merupakan persekutuan modal, didirikan berdasarkan perjanjian, melakukan kegiatan usaha dengan modal dasar yang seluruhnya terbagi dalam saham dan memenuhi persyaratan yang ditetapkan dalam undangundang ini serta peraturan pelaksanaannya". Dengan demikian BUMN yang berbentuk perseroan terbatas harus berbentuk badan hukum (rechtpersoon). Istilah Perseroan Terbatas berbeda-beda, pada jaman Belanda dikenal dengan Naamloze Vennootschap (NV), kemudian istilah Corporate Limited (Co. Ltd) juga

\footnotetext{
5 Henry Campbell, Black's Law Dictionary, Sixth Edition, St Paul Minn: West Publishing, 1992, hlm. 620.
}

dikenal pada perusahaan asing, dan Serikat Dagang Benhard (SDN BHD), namun untuk Indonesia, digunakan istilah Perseroan Terbatas atau PT. Ketentuan tersebut, menyatakan jika BUMN tidak hanya tunduk pada UU BUMN, melainkan juga UU PT.

Mengkaji kepemilikan BUMN tidak terlepas dari modal yang dimiliki BUMN. Pada pasal 4 (1) UU BUMN seperti yang telah dipaparkan sebelumnya menjelaskan jika modal BUMN berasal dari keuangan negar yang dipisahkan, penjelasannya adalah dipisahkan dari pengelolaan APBN, kemudian apakah modal tersebut terus berbentuk modal atau dana talangan yang hanya digunakan pada waktu tertentu. Ketentuan ini dijelaskan pada definisi BUMN seperti yang dijelaskan sebelumnya yaitu modal BUMN terbagi atas saham, dengan demikian saham digunakan sebagai bukti penyertaan modal dan jumlah persentasenya tergantung seberapa besar modal yang disertakan. Ketentuan ini juga diperkuat dalam Pasal 31 (1) UU PT yang menjelaskan "modal dasar Perseroan terdiri atas seluruh nilai nominal saham". Dengan demikian kepemilikan negara terhadap BUMN adalah kepemilikan saham, bukan kepemilikan modal, dan akibat hukum dari kepemilikan saham pada perseroan terbatas terdapat dalam Pasal 3 (1) UU PT yang menyatakan "pemegang saham Perseroan tidak bertanggung jawab secara pribadi atas perikatan yang dibuat atas nama Perseroan dan tidak bertanggung jawab atas kerugian Perseroan melebihi saham yang dimiliki”.

Pertanggungjawaban negara juga terbatas pada jumlah saham yang dimiliki, sehingga jika BUMN mengalami kerugian, maka kerugian tersebut secara teori merupakan kerugian badan hukum, bukan kerugian pemilik modal. Pasca putusan MK, kerugian BUMN juga menjadi kerugian negara, padahal jelas, jika kerugian tidak sebesar

6 Adrian Sutedi, Buku Pintar Hukum Perseroan Terbatas, Jakarta: Raih Asa Sukses, 2015, hlm. 7. 
nilai saham yang dimiliki maka belum terjadi kerugian. Konstruksi tersebut membawa pengertian bahwa BUMN sepenuhnya dimiliki oleh negara dan pengelolaan keuangannya tidak boleh mengalami kerugian, dan mekanisme ini sama seperti pengelolaan keuangan pada lembaga negara. Lembaga negara merupakan organ yang menjalankan negara yang sumber keuangannya berasal dari APBN sehingga penyerapan keuangan lembaga negara harus transparan dan tidak boleh diselewengkan termasuk tidak ada kata rugi dalam pengelolaan keuangan lembaga negara.

Jika aturan ini dapat dicerna dengan baik, maka putusan MK harus menjelaskan dampak pasal-pasal lain yang juga mengikat BUMN sebagai badan hukum privat. Dasar pertimbangan putusan MK adalah, penyelamatan keuangan negara yang telah diserahkan pada BUMN agar tetap dapat diawasi sehingga tidak menyebabkan penyelahgunaan modal tersebut menjadi keuntungan pribadi organ perseroan. Alasan penyelamatan tidak dibenarkan melihat organ perseroan terdiri dari direksi, komisaris dan pemegang saham, dimana pemegang saham adalah negara yang diwakilkan oleh menteri BUMN diatur dalam Pasal 1 ayat 5 UU BUMN.

\section{PENGELOLAAN MODAL BUMN}

BUMN merupakan badan usaha yang menjalankan suatu usaha dalam banyak bidang terutama sektor yang dikuasai oleh negara, dengan demikian pengelolaan BUMN tidak berbeda dengan pengelolaan Perseroan Terbatas pada umumnya sebagaimana diatur dalam UU PT, namun yang membedakan adalah modal BUMN yang tetap menjadi keuangan negara dan tetap dikontrol oleh negara, meskipun negara telah menunjuk menteri sebagai wakil negara untuk pemagang saham yang juga termasuk organ perseroan.

Jadi kontrol oleh negara terhadap keuangan BUMN dilakukan sebanyak dua kali, Pertama, Negara sebagai pemiliki modal yang mengontrol keuangan BUMN sebagai keuangan negara, melalui Pasal 2 huruf $g$ Undang-Undang No. 17 Tahun 2003 tentang Keuangan Negara, yang menegaskan: Kekayaan negara/daerah yang dikelola sendiri dan oleh atau pihak lain berupa uang, surat berharga, piutang, barang, serta hak-hak lain yang dapat dinilai dengan uang, termasuk kekayaan yang dipisahkan pada perusahaan negara /perusahaan daerah. kontrol ini juga menempatkan, jika keuangan negara yang telah dipisahkan melalui Penanaman Modal Negara (PMN) merupakan objek pemeriksaan BPK.

Kontrol kedua dilakukan oleh negara melalui menteri BUMN sebagai pemegang saham yang dapat mengontrol keuangan negara melalui kekuasaan pemagang saham mayoritas yang dapat menentukan siapa yang menjadi komisaris dan direksi pada suatu BUMN.

Penyertaan Modal Negara adalah pengalihan kepemilikan Barang Milik Negara yang semula merupakan kekayaan negara yang tidak dipisahkan menjadi kekayaan negara yang dipisahkan untuk diperhitungkan sebagai modal/saham negara pada BUMN, BUMD atau Badan Hukum lainnya. Dalam keuangan negara, penyertaan modal negara menjadi kekayaan negara yang dipisahkan yaitu kekayaan negara yang berasal dari Anggaran Pendapatan dan Belanja Negara (APBN) untuk dijadikan penyertaan modal negara pada Persero dan/atau Perum serta Perseroan Terbatas lainnya. Berdasarkan modul penatausahaan kekayaan negara yang dipisahkan yang disusun oleh Kementerian Keuangan Tahun 2007, didalamnya memuat tentang mekanisme penyertaan modal negara ke BUMN. Undang-undang No.17 Tahun 2003 tentang Keuangan Negara menyatakan surplus penerimaan negara dapat digunakan untuk membiayai pengeluaran negara/daerah sebagaimana dimaksud adalah untuk membentuk dana cadangan atau 
penyertaan pada perusahaan negara yang harus memperoleh persetujuan terlebih dahulu oleh DPR. ${ }^{7}$

Pasal 4 ayat (1) Undang-Undang No. 19 Tahun 2003 tentang yang menegaskan modal BUMN merupakan dan berasal dari kekayaan negara yang dipisahkan. Sementara itu, penjelasannya menentukan bahwa yang dimaksud dengan dipisahkan adalah pemisahan kekayaan negara dari APBN untuk dijadikan penyertaan modal negara pada Badan Usaha Milik Negara untuk selanjutnya pembinaan dan pengelolaannya tidak lagi didasarkan pada sistem APBN, namun pembinaan dan pengelolaannya didasarkan pada prinsip-prinsip perusahaan yang sehat. ${ }^{8}$ Tujuan dari dilakukan Penyertaan Modal Negara (PMN) dari Pemerintah Republik Indonesia kepada BUMN adalah untuk mengoptimalisasi Barang Milik Negara dan untuk mendirikan, mengembangkan/meningkatkan kinerja BUMN Persero. ${ }^{9}$

Institusi-institusi yang terkait dengan penatausahaan dan pengusulan Penyertaan Modal Negara pada BUMN dan Perseroan Terbatas, dengan wewenang dan tanggung jawab masing-masing meliputi:

\section{a. Kementerian Keuangan}

Sesuai UU Nomor 17 Tahun 2003, Menteri Keuangan antara lain memiliki wewenang dan tanggung jawab sebagai pengelola fiskal dan Wakil Pemerintah dalam Kepemilikan Kekayaan Negara yang dipisahkan. Di samping itu, kedudukan Menteri Keuangan berdasarkan Undang-Undang Nomor 1 Tahun 2004 adalah sebagai pengelola Barang Milik Negara. namun demikian, sesuai Peraturan Pemerintah Nomor 41

\footnotetext{
7 Kompas, Menkeu: DPR Bisa Saja Menolak Pencairan Dana PMN, www.bisniskeuangan.kompas.com diakses pada 30 Oktober 2015.

8 Muhammad Djafar Saidi dan Rohana Huseng, Hukum Penerimaan Negara Bukan Pajak, Jakarta: Raja Grafindo Persada, 2008, hlm. 16-17
}

Tahun 2003 adalah sebagaian kewenangan Menteri Keuangan terkit dengan kedudukannya sebagai wakil Pemerintah pada BUMN dilimpahkan kepada Meneteri Negara BUMN. Sedangkan kewenangan dalam rangka penatausahaan dan pengusulan PMN pada BUMN tetap berada pada Menteri Keuangan. ${ }^{10}$

Berkenaan dengan hal tersebut di atas, dan dengan pertimbangan bahwa PMN tidak saja ada pada BUMN, tetapi terdapat pula pada Perseroan Terbatas, maka selanjutnya Menteri Keungan mengatur Pedoman lebih lanjut mengenai penatausahaan dan pengusulan. Pengusulan PMN pada BUMN dan Perseroan Terbatas. Pengaturan tersebut menyangkut dokumen-dokumen yang diperlukan dalam rangka penatausahaan PMN, institusi yang terlibat, proses dokumentasi dokumen legal PMN, pencatatan PMN, dan pelaporan PMN, serta kegiatan-kegiatan terkait dengan pengelolaan kekayaan Negara yang dipisahkan, yaitu:

1) Direktorat Jenderal Kekayaan Negara c.q Direktorat Barang Milik Negara II terkait dengan pelaksanaan Penyertaan Modal Negara;

2) Badan Kebijakan Fiskal c.q. Pusat Pengelolaan Resiko Fiskal terkait dengan risk management Penyertaan Modal Negara;

3) Direktorat Jenderal Anggaran c.q. Direktorat Anggaran III terkait dengan penyusunan Anggaran

\footnotetext{
9 Modul Penatausahaan Kekayaan Negara Dipisahkan, Departemen Keuangan Republik Indonesia 2007

${ }^{10}$ Ibid
} 
Pendapatan dan Belanja Negara Bagian Anggaran

4) Direktorat Jenderal Perbndaharaan c.q.:

a) Direktorat Pengeloaan Kas Negara terkait dengan pencairan Dana Penyertaan Modal Negara;

b) Direktorat Akuntansi dan Pelaporan Keuangan terkait dengan Laporan Keuangan Pemerintah Pusat;

b. Kementerian yang ditunjuk dan/atau Diberi Kuasa Dalam Pembinaan BUMN.

Kementerian Negara BUMN memiliki wewenang dan tanggung jawab sebagai wakil Pemerintah selaku RUPS pada Persero dan pemegang saham pada Perseroan Terbatas, serta pemilik modal pada Perum. Dalam kaitannya dengan Penatausahaan dan Pengusulan PMN ini, Kementerian Negara BUMN bertanggungjawab untuk menyampaikan kepada Menteri Keuangan dokumen PMN yang tidak memerlukan Penerbitan Peraturan Pemerintah, berupa keputusan RUPS dan penerbitan.

Semua keputusan terkait dengan PMN, serta konfirmasi dan klarifikasi atas PMN pada BUMN dan Perseroan Terbatas yang ada pada kewenangannya.Terkait dengan kegiatan Pengusulan PMN, Kementerian Negara BUMN mengusulkan penambahan/ pengurangan PMN pada batas-batas kewenangannya. Terdapat beberapa Eselon I yang terkait dengan Pengelolaan Kekayaan Negara yang dipisahkan, yaitu:
a. Sekretariat Kementerian Negara BUMN;
b. Deputi Bidang Restrukturisasi dan Privatisasi.
c. Badan Usaha Milik Negara

Setiap BUMN (Persero dan Perum) berwenang untuk mengelola dan mengadministrasikan PMN yang diterimanya, dan selanjutnya bertanggung jawab dalam menyampaikan pelaporan secara periodic kepada Menteri Keuangan terkait dengan PMN yang ada pada BUMN bersangkutan dan disertai dengan Laporan Keuangan Perusahaan sebagai informasi tambahan untuk memperjelas kedudukan PMN dimaksud dalam laporan keuangan.

Adapun tata cara penyertaan modal negara dengan pemisahan kekayaan negara berbentuk modal/saham pada BUMN dilakukan melalui Penyertaan penanaman modal oleh pemerintah dan sesuai dengan Undang-Undang Nomor 9 Tahun 1969 tentang Perusahaan Negara terdahulu maupun Undang-Undang Nomor 19 Tahun 2003 tentang BUMN yang sekarang berlaku, pemisahan tersebut baik berupa setiap penambahan maupun pengurangan pada penyertaan modal Negara harus ditetapkan dengan suatu Peraturan Pemerintah.

Modal BUMN yang berasal dari kekayaan negara yang dipisahkan (Pasal 4 ayat (1) UU No. 19 Tahun 2003 tentang BUMN). Arti dipisahkan tersebut sesuai dengan penjelasan Pasal 4 ayat (1) UU No. 19 Tahun 2003 tentang BUMN, pemisahan kekayaan kekayaan dari APBN untuk dijadikan penyertaan modal negara pada BUMN untuk selanjutnya pembinaan dan pengelolaannya tidak lagi didasarkan pada sistem APBN, Namun pembinaan dan pengelolaannya didasarkan pada prinsip-prinsip pengelolaan perusahaan yang sehat.

Dari ketentuan tersebut, tampak jelas dengan dipisahkannya dari APBN maka modal/kekayaan negara menjadi "putus" hubungannya dengan APBN, sehingga ketika harta kekayaan itu 
dimasukkan/disetor kepada BUMN membawa akibat, yaitu peralihan hak milik menjadi kekayaan BUMN. Harta kekayaan tersebut bukan lagi milik negara. Hal ini sejalan dengan teori badan hukum di atas, bahwa badan hukum memiliki harta kekayaan sendiri yang terpisah dari kekayaan pendiri maupun pengurusnya.

Oleh karena pengelolaannya sudah tidak mengikuti APBN. Di dalam konsep Perseroan Terbatas modal dasar merupakan harta kekayaan perseroan sebagai badan hukum, yang terpisah dari harta kekayaan pribadi pendiri dalam hal ini Negara Republik Indonesia, organ perseroan, dan pemegang saham.

\section{PENGELOLAAN MODAL BUMN YANG BERASAL DARI KEUANGAN PRIVAT}

Sesuai dengan definisi BUMN Persero yang sebelumnya sudah diterangkan, dimana kepemilikan BUMN Persero terbagi atas saham, dan minimal dimiliki negara 51\%, agar negara tetap memegang kendali perseroan. Maka penyertaan modal juga dapat dilakukan oleh pihak swasta terhadap suatu BUMN dan perseroan terbatas.

Sebenarnya, persekutuan yang terjadi dalam Perseroan sebagai badan hukum, bukan hanya persekutuan modal, tetapi juga persekutuan para anggota yang terdiri dari pemegang saham (aandeelhouder, shareholder). Namun yang lebih menonjol adalah persekutuan modal dibanding dengan persekutuan orang atau anggotanya sebagaimana yang terdapat dalam Persekutuan yang diatur dalam pasal 1618 KUH Perdata.

Persekutuan Perdata (partnership / maatschap) menurut pasal 1618 KUHPerdata adalah perjanjian antara dua orang atau lebih mengikatnya diri untuk meamsukkan sesuatu inbreng) ke dalam persekutuan dengan maksud membagi keuntungan yang diperoleh karenanya.

Dari ketentuan Pasal 1618 KUHPerdata tersebut ,dapat beberapa unsur tyang terdapat di dalam persekutuan perdata ,yaitu :

1. adanya suatu perjanjian kerjasama antara dua orang atau lebih.

2. masing-masing pihak harus memasukkan sesuatu ke dalam persekutuan (inbreng)

3. bermaksud membagi keuntungan bersama.

Partnership dapat diartikan sebagai suatu perjanjian (agreement) diantara dua orang / lebih untuk memasukkan uang, tenaga kerja ,dan keahlian ke dalam atau lebih untuk mendapatkan keuntungan yang dibagi-bagi bersama sesuai dengan bagian atau proporsi yang telah disepakati bersama Orang (Person) yang melakukan kerjasama di dalam persekutuan tersebut dapat berupa perorangan , persekutuan perdata, perusahaan yang berabadan hukum ,atau bentuk persekutuan lainnya. Makna bisnis (business) di dalam definisi persekutuan di atas mencakup setiap aktivitas yang menjalankan perusahaan, perkerjaan, atau profesi.

Pada penyertaan modal yang dilakukan oleh pihak swasta terhadap suatu BUMN, maka ketentuan mengenai penyertaan modal tersebut, tunduk kepada ketentuan UndangUndang Nomor 40 Tahun 2007 (UU PT) dan Undang-Undang Nomor 8 Tahun 1995 (UU Pasar Modal).

Penyertaan secara langsung oleh pihak swasta terhadap suatu BUMN yang terbuka dapat dilakukan oleh investor dengan beberapa cara: a. Investasi modal ventura. $b$. Investasi penyertaan modal secara langsung pada perusahaan yang telah berdiri dan tidak tercatat di pasar modal. Biasanya dilakukan untuk memperkuat posisi keuangan perusahaan, ekspansi bisnis perusahaan atau 
dapat juga guna menyelamatkan oparasional perusahaan karena kesulitan likuiditas. ${ }^{11}$

Investasi secara langsung pada perusahaan yang telah tercatat pada pasar modal. Pada umumnya jual beli saham dilakukan dengan menggunakan jasa pialang (di Indonesia dikenal dengan istilah perusahaan perantara perdagangan efek), sedangkan mekanisme perdagangan ditetapkan oleh otoritas pasar modal dan perusahaan perantara perdagangan efek yang bersangkutan. Investasi tidak langsung pada umumnya dilakukan oleh perorangan dengan melalui penyimpanan reksadana atau bentuk lain yang khusus dari investasi dana terkumpul, sebagian besar dari mereka mencantumkan harga yang terpampang di surat kabar keuangan atau majalah majalah bisnis. ${ }^{12}$

Pada pengelolaannya, modal yang berasal dari investor swasta atau pihak lain selain pemerintah sebagai pemilik saham mayoritas, pengelolaannya tidak dibedakan, dan ini yang menjadi masalah, karena keuangan privat juga dapat dikategorikan keuangan negara jika sudah berada dalam BUMN, sementara harusnya, keuangan investor selain negara, harus dikatogorikan sebagai keuangan privat yang menjadi kekayaan korporasi dalam hal ini kekayaan BUMN.

\section{Pengelolaan Modal BUMN yang Berasal dari Penyertaan Modal Langsung terhadap Suatu Badan Usaha.}

Investasi ekuitas umumnya berhubungan dengan pembelian dan penyimpanan saham modal pada suatu pasar modal oleh investor, baik perorangan (individu) maupun perusahaan (institusi) dalam mengantisipasi pendapatan dari deviden dan keuntungan modal sebagaimana nilai saham tersebut

\footnotetext{
11 Joko Salim, Strategi Cerdas Investasi Saham, Jakarta: Elex Media Komputindo, 2011, hlm. 16-17.

${ }^{12}$ Sentanoe Kertonegoro, Analisa dan Manajemen Investasi, Edisi I, Jakarta: Widya Press, 1995, hlm. 4.
}

yang meningkat. Hal tersebut juga terkadang berkaitan dengan akuisisi saham (kepemilikan) dengan turut serta dalam suatu perusahaan swasta (tidak tercatat di bursa) atau perusahaan baru (suatu perusahaan sedang dibuat atau baru dibuat). Ketika investasi dilakukan pada perusahaan yang baru, hal itu disebut sebagai investasi modal ventura dan pada umumnya dipahami mempunyai risiko yang lebih besar dari investasi yang dilakukan pada situasisituasi dimana saham tersebut tercatat di bursa.

BUMN dimasukkan sebagai "Instansi Pemerintah" akan tetapi, BUMN itu merupakan badan hukum perdata yang tidak mempunyai kewenangan publik. Kekayaan negara yang menjadi modal dalam bentuk saham dari badan usaha tersebut tidak lagi merupakan kekayaan negara, tetapi telah berubah status hukumnya menjadi kekayaan badan usaha tersebut. Demikian pula kedudukan hukum pejabat pemerintah yang duduk sebagai pemegang saham swasta lainnya. Imunitas publiknya sebagai penguasa yang memiliki otoritas tidak berlaku lagi, dan kepadanya tunduk dan berlaku sepenuhnya hukum privat, meskipun saham perusahaan tersebut seratus persen milik negara. Sebenarnya pengelompokan BUMN sebagai instansi pemerintah atau bukan tergantung dari jenis, format, dan operasionalisasi dari BUMN itu sendiri. ${ }^{13}$

Dalam melakukan pengembangan perseroan, BUMN dapat melakukan akuisisi atau investasi terhadap suatu badan usaha, baik itu terhadap sesama BUMN atau Badan Usaha Milik Swasta (BUMS). Dengan tujuan mengembangkan potensi usaha agar mampu berkembang dan bersaing secara adil dengan perusahaan swasta lainnya. ${ }^{14}$

\footnotetext{
${ }^{13}$ Ridwan HR, Hukum Administrasi Negara, Jakarta: Raja Grafindo, 2007, hlm. 87.

${ }^{14}$ Iswi Haryani, et, al, Merger, Akuisisi, Konsolidasi dan Pemisahan Perusahaan, Jakarta: Visi Media, 2011, hlm. 332.
} 
BUMN Persero yang memang diarahkan untuk memperoleh keuntungan dalam arti, karena baiknya pelayanan yang diberikan dan pembinaan organisasi yang baik, efektif, efisien, dan ekonomi secara business zakeliik, cost accounting principles, management effectiveness, ${ }^{15}$ dan pelayanan umum yang baik dan memuaskan dengan memperoleh surplus atau laba. Status hukumnya sebagai badan hukum perdata, yang berbentuk Perseroan Terbatas.Hubungan-hubungan usahanya diatur menurut ketentuan hukum perdata. Modal pendirian BUMN Persero baik seluruhnya atau sebagian merupakan milik negara dari kekayaan negara yang dipisahkan, sehingga dengan demikian dimungkinkan adanya joint dan mixed enterprise dengan swasta (nasional dan/atau asing) dan adanya pembelian dan penjualan saham-saham perusahaan milik negara.

Sesuai dengan ketentuan Pasal 4 Ayat 5 UU BUMN, jika BUMN ingin melakukan akuisisi atau investasi terhadap suatu badan usaha baik itu BUMN atau BUMS maka ketentuan mengenai keuangan negara tidak lagi dapat diberlakukan, karena penyertaan modal tersebut tidak lagi berdaarkan keuangan negara (PMN) terhadap suatu badan usaha, melainkan antar badan usaha. Dan ketentuan ini tidak harus dibentuk dalam Peraturan Pemerintah sebagai dasar hukum penyertaan modal.

Keuangan dimaksud sudah menjadi kekayaan korporasi, seperti mendirikan anak usaha (Holding) PT Garuda Indonesia terhadap PT Citilink dan akuisisi PT Semen Gresik Tbk. (Persero) terhadap 70\% saham perusahaan asal Vietnam, Thang Long Cement Joint Stock Company (TLCC) dari Ha Noi General Export-Import Joint Stock Company, dengan nilai US\$ 157 juta. ${ }^{16}$

15 GS Le Roux, WA Lotter, Basic Principles of Cost and Management Accounting, Lansdowne: Juta \& Co. Ltd, 2006, hlm. 1.

\section{KESIMPULAN}

BUMN Persero, secara bentuk hukum merupakan Badan Hukum Privat, namun teknis pengelolaan keuangan dapat menyerupai pengelolaan keuangan pada instansi pemerintah. Hal ini membuat BUMN sulit untuk lebih leluasa dalam melakukan proses pengembangan usaha, karena kontrol pemerintah pada BUMN lebih kepada kontrol terhadap lembaga negara. Sementara BUMN merupakan korporasi yang memiliki fungsi sebagai pencari keuntungan, sehingga keuntungan tersebut memberikan kontribusi terhadap pendapatan negara. Baik Pasal 2 (g) UU Keuangan Negara dan Putusan Mahkamah Konstitusi No 62/PUU-XI/2013 bertujuan untuk memberikan jaminan terhadap keuangan negara untuk tidak disalahgunakan oleh korporasi (BUMN), namun jika negara tidak takut mengalami kerugian, sebaaiknya mencari format baru untuk mendapatkan keuntungan, karena konsep seperti ini sangat rentan terhadap intervensi pada BUMN dalam melakukan pengembangan usaha, dan juga BUMN akan sulit untuk menggunakan modal karena tekanan Bussines Risk yang tidak diakui dalam UU Keuangan Negara.

\section{DAFTAR PUSTAKA}

\section{Buku dan Artikel Ilmiah}

Adrian Sutedi, Buku Pintar Hukum Perseroan Terbatas, Jakarta: Raih Asa Sukses, 2015.

Carl Joachim Frederich, The Philosophy of Law in Historical Presfective, Second Edition, Chicago: University Chicago Press, 1968.

\footnotetext{
16 Semen Gresik Akuisisi 70\% Saham Perusahaan Vietnam, www.swa.co.id diakses 5 Mei 2015
} 
GS Le Roux, WA Lotter, Basic Principles of Cost and Management Accounting, Lansdowne: Juta \& Co. Ltd, 2006.

Henry Campbell, Black's Law Dictionary, Sixth Edition, St Paul Minn: West Publishing, 1992.

Iswi Haryani, et, al, Merger, Akuisisi, Konsolidasi dan Pemisahan Perusahaan, Jakarta: Visi Media, 2011.

Joko Salim, Strategi Cerdas Investasi Saham, Jakarta: Elex Media Komputindo, 2011.

Kompas, Menkeu: DPR Bisa Saja Menolak Pencairan Dana PMN, www.bisniskeuangan.kompas.com diakses pada 30 Oktober 2015.

Modul Penatausahaan Kekayaan Negara Dipisahkan, Departemen Keuangan Republik Indonesia 2007.

Muhammad Djafar Saidi dan Rohana Huseng, Hukum Penerimaan Negara Bukan Pajak, Jakarta: Raja Grafindo Persada, 2008.

Notonagoro, Politik Hukum dan Pembangunan Agraria, Jakarta: Bina Aksara, 1984.

Poan Muhammad Fariz, Penafsiran Konsep Penguasaan Negara Berdasarkan Pasal 33 UUD 1945 dan Putusan Mahkamah Konstitusi, www.jurnalhukum.blogspot.co.id diakses 5 Agustus 2015.

R. Wiratno, dkk, Ahli-Ahli Pikir Besar tentang Negara dan Hukum, Jakarta: Pembangunan, 1958.

Ridwan HR, Hukum Administrasi Negara, Jakarta: Raja Grafindo, 2007.
Semen Gresik Akuisisi 70\% Saham Perusahaan Vietnam, www.swa.co.id diakses 5 Mei 201

Sentanoe Kertonegoro. Analisa dan Manajemen Investasi. Edisi I. Jakarta: Widya Press, 1995. 